BOGDAN WALCZAK

Akademia im. Jakuba z Paradyża w Gorzowie Wielkopolskim

\title{
Urszula Sokólska, O mowo polska, ty ziele rodzime... Wokót refleksji nad ksztaltem polszczyzny. Wydawnictwo Prymat, Białystok 2017, ss. 337
}

O celu swojej monografii tak pisze sama autorka:

„Oglądowi zostaną w niej poddane istotne wątki refleksji na temat polszczyzny, ujawnione w pismach wybitnych przedstawicieli nauki i ludzi pióra. W części pierwszej znajdą się rekonstrukcje i interpretacje świadomości językowej, formułowanej w pismach znamienitych uczonych XIX oraz przełomu XIX i XX wieku (Joachima Lelewela, Jana Karłowicza, Zygmunta Glogera), w części drugiej - zostaną przedstawione racjonalne opinie i językoznawcze emocje ludzi pióra (Juliana Tuwima, Melchiora Wańkowicza, a w rozdziale poświęconym metaforyce również Stanisława Barańczaka, Tadeusza Boya-Żeleńskiego, Władysława Broniewskiego, Konstantego Ildefonsa Gałczyńskiego, Witolda Gombrowicza, Jarosława Iwaszkiewicza, Mieczysława Jastruna, Anny Kamieńskiej, Marii Konopnickiej, Ryszarda Krynickiego, Teofila Lenartowicza, Bolesława Leśmiana, Kornela Makuszyńskiego, Czesława Miłosza, Wiesława Myśliwskiego, Cypriana Kamila Norwida, Tadeusza Różewicza, Henryka Sienkiewicza, Leopolda Staffa, Juliana Tuwima, Jana Twardowskiego, Melchiora Wańkowicza, Stanisława Wyspiańskiego i kilku innych mniej znanych twórców)" (s. 10).

Oczywiście ma rację autorka, kiedy dalej stwierdza:

„Monografia niniejsza kładzie nacisk przede wszystkim na czynniki kształtujące stosunek wybitnych jednostek kulturotwórczych do języka narodowego i narodowej kultury, sygnalizuje elementy budujące i porządkujące świadomość jednostki na tle polskiej grupy etnicznej oraz ukazuje sposoby eksponowania przez niejęzykoznawców problematyki lingwistycznej" (s. 10).

Realizację tego celu odnotowuje w Posłowiu:

„Na prezentowaną książkę złożyły się refleksje lingwistyczne kilku wybitnych osobowości szeroko pojętej kultury polskiej XIX i XX wieku: trzech przedstawicieli nauki i kilkunastu wybranych reprezentantów literatury pięknej. Wszystkich ich charakteryzuje oparta na doświadczeniu zbiorowości - wysublimowana społeczna świadomość językowa, niemalże granicząca ze świadomością lingwistyczną [autorka już na wstępie relacjonuje dyskusję na temat tych pojęć i deklaruje swoje, jak najbardziej zasadne, w tym względzie stanowisko - B.W.]. Z analizowanych pism bez mała jednogłośnie wyłania się troska 
o właściwy kształt polszczyzny, traktowanej z reguły jako dobro narodowe i dobro kultury [...]” (s. 297). „Refleksje lingwistyczne - przyjmujące nierzadko postać mniejszych bądź większych traktatów naukowych - krążą wokół dwóch zasadniczych kwestii - jaki jest język polski i jaki być powinien język polski” (s. 297).

W moim przekonaniu autorka zasadnie odnotowuje w Posłowiu urzeczywistnienie celu monografii. Może komuś trochę brakować eksplicytnej deklaracji w kwestii zastosowanego w pracy instrumentarium badawczego, mnie się jednak wydaje, że autorka wolała ukazać to instrumentarium w działaniu, zamiast je opisywać. Jest to mianowicie instrumentarium nowoczesnego historyka języka polskiego, przyjmującego, że uprawiana przez niego dyscyplina ma charakter polimetodologiczny. I taką też polimetodologię (na którą się składają metody z zakresu paradygmatu badawczego komunikologii, lingwistyki kulturowej i genologii lingwistycznej) stosuje w pracy - w swoich analizach o charakterze tekstologicznym, nierzadko z pogranicza stylistyki lingwistycznej i retoryki.

Tak więc uznaję, że autorka, zgromadziwszy bardzo obszerny materiał językowy (o czym jeszcze niżej) i uzbrojona w polimetodologiczne instrumentarium badawcze, osiągnęła zamierzony cel badawczy. Powstała praca wybitna, o której wartości stanowią w moim przekonaniu przede wszystkim następujące aspekty i okoliczności:

1) Wybór tematu. Choć ostatnio ukazało się kilka prac w rodzaju monografii Mirosławy Sagan-Bielawy (o społecznej świadomości językowej w Drugiej Rzeczypospolitej), wciąż jeszcze niewiele wiemy (a w każdym razie nasza wiedza w tym względzie nie jest satysfakcjonująca) o stosunku ludzi kultury (nowszych czasów) do tworzywa tej kultury w jej wymiarze intelektualnym i artystycznym, jakim jest język polski. Każda więc obszerniejsza i udokumentowana (o co najtrudniej) praca na ten temat jest bardzo pożądana.

2) Podstawa źródłowo-materiałowa. Jest ona wyjątkowo solidna i obszerna. Sam spis źródeł (bibliografia podmiotu w ujęciu autorki) zajmuje aż 6 stron i obejmuje wiele prac naukowych Zygmunta Glogera, Joachima Lelewela i Jana Karłowicza oraz tomy (częściej poezji, rzadziej prozy) Stanisława Barańczaka, Mirona Białoszewskiego, Tadeusza BoyaŻeleńskiego, Władysława Broniewskiego, Konstantego Ildefonsa Gałczyńskiego, Tomasza Jastruna, Michała Kajki, Marii Konopnickiej, Ryszarda Krynickiego, Teofila Lenartowicza, Bolesława Leśmiana, Karola Libelta, Kornela Makuszyńskiego, Adama Mickiewicza, Czesława Miłosza, Cypriana Kamila Norwida, Or-Ota, Tadeusza Peipera, Romana Ludwika Pisarskiego, Tadeusza Różewicza, Henryka Sienkiewicza, Leopolda Staffa, Władysława Syrokomli, Edwarda Szymańskiego, Świeżawskiego, Juliana Tuwima, Melchiora Wańkowicza, Stanisława Wyspiańskiego czy Stefana Żeromskiego. Ponieważ autorka dokonała gruntownej metaleksykograficznej analizy Tuwimowskiego Słownika pijackiego, dołączyła rozwiązanie zastosowanych tam symboli w liczbie 434, co zajęło kolejnych 5 stron. Taka solidna podstawa źródłowo-materiałowa umożliwia wiarygodne wnioski i w ogóle gwarantuje ważne wyniki naukowe. Charakteryzuje też dobrze warsztat naukowy autorki i pozwala na przypuszczenie, że jest ona zdania (wspólnego ze zdaniem recenzenta), iż językoznawstwo jest nauką empiryczną.

3) Imponujące zaplecze erudycyjne pracy. Wykaz bibliograficzny (literatura przedmiotu w ujęciu autorki), w którym nie dostrzegam żadnych istotnych luk, obejmuje aż 248 pozycji, z czego niemal połowę, gdyż 115, stanowią książki, nieraz wielotomowe. Osobno zestawiła autorka 28 wyzyskanych słowników i encyklopedii - tu już wyłącznie książek. Godzi się też zauważyć, że choć bibliografia obejmuje wyłącznie prace polskojęzyczne, są 
wśród nich polskie przekłady uczonych zagranicznych, na przykład Michela Foucaulta, Hansa-Georga Gadamera, Johanna Gottfrieda Herdera czy Edwarda Sapira.

4) Wnikliwość, dociekliwość i precyzja prezentowanych analiz i interpretacji. Warto zauważyć, że dowodzą one znakomitego wyczucia stylistycznej wartości słowa. Jest to ważne, gdyż w moim przekonaniu drewniane ucho badacza jest główną przyczyną fiaska analiz stylistycznych - niezależnie od przyjmowanego paradygmatu badawczego: jest po prostu tak, że albo się „,czuje” słowo, albo się go „nie czuje”.

5) Jako skutek wyliczonych wyżej walorów - ważne i dobrze udokumentowane wyniki naukowe. Jest ich wiele - tak ogólnych, jak i szczegółowych, i wolno sądzić, że różne wyniki szczególnie zainteresują różnych czytelników książki Urszuli Sokólskiej (a myślę, że oprócz językoznawców będą wśród nich także literaturoznawcy i kulturoznawcy). Najważniejsze wyniki autorka bardzo zgrabnie zestawiła w Posłowiu (s. 297-301). Osobiście zwróciłbym uwagę na kilka z nich :

„Język rodzimy jest ostoją bytu i centrum ducha narodu” (s. 297).

„Wątki językowe ściśle łączą się z historią polskiego społeczeństwa, cywilizacyjnym rozwojem narodu i jego kultury [..]” (s. 297).

„Należy chronić i pielęgnować mowę ludu, stanowiącą integralną część języka ogólnego, gdyż to w niej skrywają się pierwotne skarby i ślady pradawnej kultury etnicznej" (s. 298).

„Trzeba bezwzględnie rozwijać wśród użytkowników polszczyzny językową świadomość i wiedzę o języku. Budzenie tej świadomości jest rolą wybitnych pisarzy i wielkich uczonych, którzy powinni być uznani za kodyfikatorów normy językowej” (s. 298).

„Norma językowa nie jest czymś niezmiennym, [...] lecz ulega ciągłemu doskonaleniu” (s. 299).

„Język artystyczny jest jednym z ważniejszych elementów odkrywania przeszłości języka" (s. 299).

„Wypowiedzi naukowców o języku są mniej emocjonalne, a pod względem strukturalnym i semantycznym bardziej sformalizowane i zracjonalizowane [...]. Różnica w ujmowaniu języka wśród ludzi reprezentujących różne dyscypliny humanistyczne wynika z tradycyjnie ugruntowanej odmienności stylistyczno-emocjonalnej między dysputą naukową a wypowiedzią artystyczną. Pierwszej narzucono porządek, wyważony osąd, racjonalizm i harmonię stylistyczną, w drugiej dopuszczono elementy daleko wykraczające poza zdroworozsądkowe ramy, czyli przewagę subiektywizmu nad obiektywizmem oraz łamanie obowiązujących reguł gramatycznych, przeobrażające się chwilami w nieokiełznane szaleństwo językowe" (s. 300).

6) I na koniec - umiejętności pisarskie Urszuli Sokólskiej, która jest świetną stylistką i pisze jasno, klarownie, atrakcyjnie i - w miarę możliwości - przystępnie. Umiejętność klarownego przedstawienia rzeczy trudnych może najlepiej się uwidacznia przy opisie i interpretacji wypowiedzi zmetaforyzowanych.

Choć praca jest bardzo obszerna i merytorycznie „gęsta” (miejscami, mimo stylistycznych umiejętności autorki, aż trudna w lekturze na skutek mnogości wtrętów, odwołań literaturowych itd.), usterek w niej właściwie nie ma (poza drobiazgami pisowniowymi i redakcyjnymi w wykazie bibliograficznym - gdzie znajdujemy na przykład Majenowa (zam. Mayenowa) czy Martyja (zam. Matyja) albo dwukrotnie powtórzoną publikację Marii Malec Nazwy osobowe. Antroponimia). Można więc z pełnym przekonaniem stwierdzić, że 
książka Urszuli Sokólskiej O mowo polska, ty ziele rodzime ... Wokół refleksji nad ksztattem polszczyzny to praca wybitna, która zajmie poczesne miejsce $\mathrm{w}$ dorobku polskiego językoznawstwa. 